\title{
ATIVISMO JUDICIAL E SEUS LIMITES FRENTE À CONSTITUIÇÃO
}

\author{
Luma Gomes Gândara ${ }^{1}$ \\ João Carlos Fazano Sciarini ${ }^{2}$
}

\begin{abstract}
RESUMO: O ativismo judicial decorre de uma atuação proativa do Poder Judiciário, atuando incisivamente na concretização de direitos, a fim de lhes conferir a almejada efetividade, conforme estatui a Constituição Federal de 1988. O presente artigo buscou fazer uma análise acerca do ativismo judicial, desde suas concepções básicas, no que tange à conceituação, aspectos positivos e negativos, bem como identificação do fenômeno. Num segundo momento, foram estudadas as teorias procedimentalistas, substancialistas e as críticas que são feitas a ambas. Traçadas as bases nos primeiros capítulos, coube ao último tratar do papel e dos limites do ativismo judicial em face da Constituição Federal.
\end{abstract}

PALAVRAS-CHAVE: Ativismo Judicial. Teoria Procedimentalista. Teoria Substancialista. Poder Judiciário. Constituição Federal.

\section{JUDICIAL ACTIVISM AND ITS LIMITS IN FRONT OF THE CONSTITUTION}

\begin{abstract}
Judicial activism stems from a proactive action by the Judiciary, acting incisively in the realization of rights, in order to give them the desired effectiveness, as established by the Federal Constitution of 1988. The present article sought to analyze judicial activism from its Conceptions, positive and negative aspects, as well as identification of the phenomenon. In a second moment, the proceduralist, substantialist theories and the criticisms that have been made of both are studied. Once the bases were laid out in the first chapters, it was up to the latter to deal with the role and limits of judicial activism in the face of the Federal Constitution.
\end{abstract}

KEYWORDS: Judicial Activism. Proceduralist Theory. Substancialist Theory. Judicial power. Federal Constitution.

\footnotetext{
${ }^{1}$ Escrevente Técnica Judiciária no TJSP. Mestranda em ciência jurídica pela Universidade Estadual do Norte do Paraná (UENP), área de concentração: Teorias da Justiça: Justiça e Exclusão, linha de pesquisa: Função Política do Direito; possui especialização em Direito Civil e Processo Civil pelo Projuris/FIO (2016); possui graduação em Direito pela UENP (2014); e-mail: lgandara@tjsp.jus.br

${ }^{2}$ Advogado, Especialista em Direito Civil e Processual Civil pela UEL (2013), Especialista em Direito do Trabalho e Direito Previdenciário pela FEMA (2018). Possui graduação em Direito pela FEMA (2011), e-mail: jcsciarini@gmail.com
} 


\section{INTRODUÇÃO}

É certo que um dos princípios basilares do Estado Democrático de Direito é o princípio da separação de poderes, de modo que existem funções típicas ao Executivo, Legislativo e Judiciário.

Partindo-se dessa premissa inicial, pode-se dizer que cabe ao Poder Legislativo a função de legislar, por meio da legitimação que lhe é conferida pelo povo, atuando este como verdadeiro representante dos interesses da coletividade. E, cabe ao Poder Executivo a função de executar a vontade legislativa.

No entanto, por vezes, as funções de cada poder não são exercidas a contento e diante do quadro de inefetividade de direitos fundamentais ou de uma falha de representatividade dos anseios populares, o Poder Judiciário passa a atuar intensa e ativamente, de modo a efetivar os direitos fundamentais agasalhados pela Carta Maior, confiando verdadeiro efeito normativo às suas decisões.

Essa participação afirmativa, proativa e, por vezes, criativa do Poder Judiciário recebe o nome de ativismo judicial.

As sociedades modernas estão cada vez mais exigentes e necessitadas no que diz respeito à concretização de seus direitos e garantias fundamentais sob a égide da Constituição Federal, mas as políticas públicas e atuações dos Poderes Executivo e Legislativo não correspondem à realização desses direitos, recaindo sobre o Poder Judiciário que, com as ferramentas de que dispõe, vale dizer, fazendo uso da supremacia da Constituição Federal com decisões de grande carga axiológica e principiológicas, tenta minimizar os problemas, dando corpo às teorias substancialistas.

Por outro lado, em um Estado Democrático de Direito, quando acareado com o princípio da tripartição de poderes, o ativismo judicial é visto com certa temeridade por alguns, e com repugnância por outros, por apontar, em tese, uma condenável afronta à democracia. Nesse sentido, os adeptos das teorias procedimentalistas, ganham piso ao se verificar, cada vez mais, decisões judiciais com verdadeira carga de decisões políticas, extrapolando seus limites 
precípuos de atuação, quando deveriam cultivar a autocontenção judicial. Isto posto, sob o olhar procedimental, essa postura do Judiciário não se mostra legítima.

Daí exsurge a necessidade de se entender os pontos e contrapontos de teóricos procedimentalistas e substancialistas na busca por uma teoria constitucional adequada que respeite os limites achados por um Estado Democrático de Direito.

Serão utilizadas como técnicas de pesquisa, de forma a coletar e examinar os materiais analisados, a pesquisa indireta documental e bibliográfica, por meio de doutrinas e artigos acerca dos assuntos a serem trabalhados.

\section{ATIVISMO JUDICIAL: UMA INTERFERÊNCIA (IN)ADEQUADA DO PODER JUDICIÁRIO NA ESFERA DE ATUAÇÃO DOS DEMAIS PODERES}

O ativismo judicial tem suas raízes fincadas em terras estrangeiras, sendo uma expressão cunhada e amplamente usada nos Estados Unidos. É considerado um fenômeno jurídico, comumente designado como uma postura arrojada do Poder Judiciário na interferência de maneira regular e significativa nas opções políticas dos demais poderes.

\subsection{Aspectos conceituais}

A expressão “ativismo judicial” é relativamente recente. No entanto, a ocorrência do fenômeno precede a utilização do termo. Como aponta Oscar Valente Cardoso:

[...] no século XIX já havia menção doutrinária à existência de uma "legislação judicial” (“judicial legislation”), para designar a atitude de juízes elaborando normas próprias (“judges making positive law”). No século XVIII, William Blackstone mencionava a judicial legislation como a principal característica do Common Law, Jeremy Bentham afirmava constituir uma usurpação do legislativo e, no século seguinte, John Austin defendia sua prática (CARDOSO, 2013, p. 76).

Hoje ministro do Supremo Tribunal Federal, o Tribunal Constitucional brasileiro, Barroso ensina que as origens do ativismo judicial é essencialmente conservadora ao dizer que:

Foi na atuação proativa da Suprema Corte que os setores mais reacionários encontraram amparo para a segregação racial (Dred Scott v. Sanford, 1857) e para a invalidação das leis sociais em geral (Era Lochner, 1905-1937), culminando no confronto entre o Presidente Roosevelt e a Corte, com a mudança da orientação jurisprudencial contrária ao intervencionismo estatal (West Coast v. Parrish, 1937). A situação se inverteu completamente a partir da década de 50, quando a Suprema Corte, sob a presidência de Warren (1953-1969) e nos primeiros anos da Corte Burger (até 1973), produziu jurisprudência progressista em matéria de direitos fundamentais, sobretudo envolvendo negros (Brown v. Board of Education, 1954), acusados em processo criminal (Miranda v. Arizona, 1966) e mulheres (Richardson v. Frontiero, 
1973), assim como no tocante ao direito de privacidade (Griswold v. Connecticut, 1965) e de interrupção da gestação (Roe v. Wade, 1973) (BARROSO, 2012, p. 26).

Não obstante essas ocorrências históricas, é correto dizer que o termo "ativismo judicial”, ou em inglês “judicial activism”, foi utilizado pela primeira vez no artigo escrito por Arthur Schlesinger Jr., em 1947, publicado na revista Fortune (CARDOSO, 2013, p. 76). Logo, por óbvio, seria um anacronismo utilizar a expressão “ativismo judicial” para se referir a período anterior a 1947.

O artigo foi escrito em um contexto de promoções consideráveis de mudanças nas práticas políticas pela Suprema Corte americana, principalmente, no tocante a direitos fundamentais, mas sem que a discussão envolvesse a participação dos órgãos representativos do povo, ou seja, sem a participação dos Poderes Legislativo e Executivo (BARROSO, 2012, p. 26).

A partir de então, o termo passou a ter uma carga conotativa bastante negativa, visto que concebia o exercício indevido de uma função imprópria e inadequada do Poder Judiciário.

Deste ponto em diante, o termo foi largamente difundido e utilizado na jurisprudência americana, rapidamente se espalhando a outros países, designando o ativismo como interferência do Judiciário em questões, via de regra, políticas, seja na elaboração ou execução de políticas públicas.

\subsection{Essência do fenômeno}

Cumpra-se alertar para o fato de que não se encontra na doutrina um conceito estanque sobre o que se entende por ativismo judicial, sendo difícil a delimitação do termo, mas, concomitantemente, necessário o melhor entendimento de suas acepções para análise do fenômeno à luz das teorias substanciais e procedimentais da Constituição.

Dimitri Dimoulis e Soraya Lunardi apontam para a possibilidade de se entender o termo sobre dois vieses: um quantitativo e outro qualitativo. O viés quantitativo diz respeito à frequência ou quantidade de vezes em que o Judiciário intervém na decisão dos demais Poderes. Nesse sentido, seria ativista o magistrado que o faz demasiadamente, afetando a separação e o equilíbrio entre eles. Entretanto, de pronto se reconhece a fragilidade dessa vertente, que, aponta os autores, reside no fato de que não se tem a definição do que seria pouco ou muito para dizer se determinado juiz ou Tribunal é ou não ativista: 
Ainda que se estabeleça um quadro comparativo no tempo e entre países, mostrando uma atividade particularmente intensa em certo período ou país, isso não permite concluir algo sobre o "ativismo", pois o grande número de declarações de inconstitucionalidade não significa que um tribunal seja ativista. Sua atividade intensa pode ser consequência da atuação sistemática do legislador em desrespeito à Constituição ou da amplitude das competências judiciais em certo ordenamento. (DIMOULIS; LUNARDI, 2011, p. 461-462).

Sob o aspecto qualitativo, pouco importa a frequência, mas os critérios utilizados:

Essa perspectiva é promissora, mas exige que sejam formulados critérios claros, deduzidos de uma teoria de interpretação do direito. [...] Isso se deve à dificuldade de distinguir entre ativismo qualitativo e atuação inconstitucional-ilegal do julgador. Aquele que atua além dos limites constitucionalmente estabelecidos contraria a Constituição e abandona o papel de seu guardião. Em tais casos, quem se refere ao ativismo usa um eufemismo para a violação do direito (DIMOULIS; LUNARDI, 2011, p. 462).

De um modo geral, embora haja dificuldade teórica na adoção estanque de um conceito uníssono sobre o termo, a maioria da doutrina entende ser o ativismo um modo pró-ativo e expansivo de interpretação constitucional, inclusive para levá-la a situações que não foram expressamente contempladas pelo constituinte ou mesmo pelo legislador ordinário, assumindo posturas não previstas ou não respaldadas pela legislação.

Trata-se, na verdade, de uma questão de interpretação da Constituição em face dos limites que ela trás.

Barroso ensina que:

A ideia de ativismo judicial está associada a uma participação mais ampla e intensa do judiciário na concretização dos valores e fins constitucionais, com maior interferência no espaço de atuação dos outros dois Poderes. A postura ativista se manifesta por meio de diferentes condutas, que incluem: (i) a aplicação direta da Constituição a situações não expressamente contempladas em seu texto e independentemente de manifestação do legislador ordinário; (ii) a declaração de inconstitucionalidade de atos normativos emanados do legislador, com base em critérios menos rígidos que os de patente e ostensiva violação da Constituição; (iii) a imposição de condutas ou de abstenções ao Poder Público, notadamente em matéria de políticas públicas” (BARROSO, 2009, p. 06).

Bredley Cânon, estabelece cinco critérios para dizer se determinada decisão é ou não ativista: em primeiro lugar, uma decisão ativista apresenta um alto grau de superação das decisões tomadas pelo Legislativo e Executivo, quase sempre em defesa de direitos fundamentais. Como segundo critério, o autor americano aponta para uma ruptura com a jurisprudência anterior, ou seja, romper com a estabilidade na interpretação. Em terceiro, que a nova interpretação fuja ao sentido comum das palavras adotadas nos dispositivos objetos da 
interpretação. Em quarto, se a decisão do magistrado, Tribunal ou Corte apenas garante direitos de minorias insulares sem que isso altere ou afete o jogo democrático, essa decisão não seria ativista. Em quinto, como último critério, a decisão ativista deve trazer uma inovação no direito, vale dizer, a decisão cria direitos antes inexistentes (CÂNON, 1983, apud ALVES, 2012, p. 104).

Elival da Silva Ramos traz um conceito sobre ativismo judicial ao dizer que compreende uma “disfunção no exercício da função jurisdicional, em detrimento, notadamente, da função legislativa” (RAMOS, 2010, p. 107).

Para Anderson Vichinkeski Teixeira o ativismo:

[...] é apenas um dos sintomas mais flagrantes de que as sociedades de massa da era pós-moderna não se satisfazem mais com as prestações de serviços públicos e tutela de direitos individuais ainda nos moldes do Estado Moderno; este se revela incapaz de lidar com as necessidades e demandas que crescem em um ritmo frenético no seio da sua própria população. [...] Mais do que uma discussão acerca da separação dos poderes, o ativismo judicial nos propõe uma discussão acerca do que atualmente representam os limites entre Direito e Política. (TEIXEIRA, 2012, p. 42).

Inegável que a atuação ativista do judiciário possa trazer uma dose de temeridade a uma parcela dos doutrinadores, entretanto, por outro lado, não se pode negar que ela possa ter uma face positiva, o que significa dizer que ela aponta para o fato de que o Poder Judiciário está atendendo a demandas sociais importantes que, eventualmente, não foram atendidas pelos demais poderes em momentos adequados.

Entretanto, em que pese se considerar que o Poder Legislativo, localizado como instância política por excelência, muitas vezes não consegue atender a todos os anseios da sociedade, não se pode desejar, a despeito disso, expansão crescente, indefinida e ilimitada do Poder Judiciário.

Nesse aspecto, importante ressaltar que não se pode confundir ativismo judicial com o fenômeno sociopolítico independente da postura do Judiciário que é a judicialização da política, consistente em diversas questões adentram à esfera jurídica, ainda que outrora alheia a ela, e isso faz com que o Poder Judiciário, indubitavelmente, se pronuncie sobre aspectos políticos da realidade.

O cerne do ativismo judicial reside na invasão de competência dos Poderes Legislativo e Executivo pelo Poder Judiciário, verdadeiramente criando direitos. Notadamente e, com mais 
frequência, isso ocorre em relação ao Poder Legislativo quando se trata de omissões legais ligadas a direitos fundamentais, em que se editam normas novas para suprir tais lacunas. No tocante à invasão na esfera de atuação do Poder Executivo, geralmente ocorre em decisões que determinam a execução ou implementação de certos direitos que, em última análise, afetam o planejamento e orçamento do Estado.

Pode-se, então, formular algumas proposições: o termo “ativismo judicial” é utilizado desde o século passado e designa quase sempre uma crítica à interferência inadequada do Judiciário na esfera de atuação dos demais poderes, de modo que as questões controvertidas deveriam, em tese, serem discutidas e decididas por quem representa a vontade popular, ou seja, por seus legitimados democraticamente; o termo não encontra um significado unívoco, podendo apontar para um protagonismo do magistrado no processo (DIMOULIS; LUNARDI, 2011, p. 470).

Pois bem, vencidas algumas considerações acerca do fenômeno mundial do ativismo judicial, impõe-se o enfrentamento das posturas procedimentalistas e substancialistas - sem ignorar suas fragilidades - na tentativa de explicar a localização - constitucional - do Poder Judiciário.

\section{UMA ANÁLISE DAS TEORIAS PROCEDIMENTALISTAS E SUBSTANCIALISTAS}

Há que se reconhecer que a Constituição em muitos pontos não se mostra plenamente efetiva, daí a importância de se ressaltar a necessária discussão do atual papel do Poder Judiciário, da jurisdição constitucional e da própria Constituição.

Segundo Lassale, onde a constituição escrita não corresponder à constituição real, haverá o surgimento de um conflito inevitável, em que a constituição escrita, ou seja, a folha de papel sucumbirá ante aos imperativos das forças vitais e verdadeiras de um país (apud BOTELHO, 2010, p. 177).

Diante disso e, visando a eficácia social da norma, isto é, "sua real obediência e aplicação no mundo dos fatos” (SARLET, 2012, p. 237), admite-se, a possibilidade de intervenção da justiça constitucional na implementação de políticas públicas para que se alcance a maior efetividade possível dos direitos agasalhados constitucionalmente (STRECK, 2003, p. 260). 
À ideia de Estado Democrático de Direito se associa a de realização dos direitos fundamentais, de modo que a noção de Estado também é indissociável do conteúdo material de que se revestem as Constituições. Nesse diapasão, a lei exsurge como instrumento direcional das ações estatais para o cumprimento do apontado na Constituição.

Considerando esse cenário, o Poder Judiciário desponta como instituição responsável para a liquidação do que Streck chama de "promessas da modernidade”, havendo, por conseguinte um “deslocamento da esfera de tensão, até então calcada nos procedimentos políticos, para os procedimentos judiciais” (STRECK, 2003, p. 262).

Chega-se, então, à questão de se perquirir se pode o Poder Judiciário criar direito a partir da Constituição diretamente ou somente se pode fazê-lo pela via procedimental. Além disso, de se refletir a dimensão a ser privilegiada: a procedimental ou a substantiva.

\subsection{Teoria procedimentalista}

Alinhado ao aspecto democrático da Constituição, tem-se, para o procedimentalismo, que a Constituição não é um projeto ou um plano diretor que deve assegurar prestações sociais. Rejeitam-se excessos nas regulações de direitos ou valores contidos nos textos constitucionais, de modo que a Constituição deve ser vista procedimentalmente como autolimitada e promovedora de mecanismos que evitem que critérios políticos, morais ou valorativos interfiram na dinâmica do ordenamento jurídico de uma sociedade (ESPINOZA, 2009, p. 55).

Destarte, a intermediação dos dissensos seria passível de ser trabalhada por meio da autorregulação social - aproximando-se da democracia deliberativa proposta por Habermas -, bem como seria possível a coexistência de pluralidades políticas a partir da acepção procedimental da Constituição.

Aliás, sobre o ponto, Marcos César Botelho afirma que "na compreensão habermasiana, a Corte Constitucional não pode “criar” o Direito. Seu papel é apenas de aplicação da norma, de concretização” (2010, p. 208).

Habermas entende que a Constituição não deve ser compreendida como um texto no qual se estabelece uma ordem jurídica global, mas sim ser entendida como um instrumento para que os cidadãos se autodeterminem a partir de procedimentos políticos (ESPINOZA, 2009, p. 55). 
As teorias do jurista alemão são apresentadas por Espinoza, que, a respeito da proposta procedimental de Jurgen Habermas, diz:

A concepção procedimental da Constituição resulta da própria compreensão do autor de que o direito contemporâneo deve assentar-se num paradigma procedimental, o único possível de assegurar, ao mesmo tempo, os dois pressupostos legitimantes da ordem jurídica: a autonomia privada e a autonomia pública dos cidadãos (ESPINOZA, 2009, p. 55).

E continua:

Desse modo, a atuação da Jurisdição constitucional, sob pena de ofensa ao princípio da separação dos poderes e à legitimidade democrática de produção do direito, deve ser restrita à proteção do sistema de direitos que assegurem a autonomia privada e pública (ESPINOZA, 2009, p. 56).

A teoria habermasiana defende que o Tribunal Constitucional não deve se apresentar como protetor de valores substanciais em uma ordem suprapositiva, mas se limitar a compreender a Constituição em sua acepção procedimental, contendo-se em proteger a criação democrática do Direito por meio do processo (STRECK, 2003, p. 264).

Outro teórico defensor da teoria procedimental é John Hart Ely, que compartilha do paradigma procedimentalista e rejeita a jurisprudência de valores, bem como a ideia de princípios orientando e dirigindo interpretações. O autor defende que a imparcialidade do Tribunal Constitucional somente será conservada se seus membros não se ocuparem de preencher suas decisões com juízos de valores morais (STRECK, 2003, p. 264).

A teoria de Ely tem como cerne a "precedência do princípio democrático sobre princípios e direitos substantivos, e na ilegitimidade dos juízes para adotarem decisões substantivas de valor em um regime democrático” (MELLO, 2004, p. 41).

A resolução que Ely propõe para se evitar a inserção das subjetividades pessoais dos magistrados em suas decisões é a de que a integridade do processo democrático seja mantida através de tomadas de decisões pelos representantes do povo e, somente por eles, excluindo, portanto, interpretações carregadas de valores morais por juízes irresponsáveis politicamente (MACHADO, 2012, p. 133).

Da teoria de Ely, infere-se que as decisões substantivas tomadas pelos representantes do povo não podem ser reduzidas ou substituídas pelos juízos valorativos dos Tribunais Constitucionais, que devem, na verdade, garantir que as vias democráticas de 
discussão/deliberação sejam desbloqueadas, sem, contudo, desprezar as vozes das minorias, tampouco deixá-las serem suprimidas pela maioria, garantindo sua permanência no processo de representação, como parte integrante que são do processo democrático (MACHADO, 2012, p. 136).

Os argumentos trazidos à discussão pelos teóricos do procedimentalismo são inegavelmente fortes e bem projetados, entretanto, não são imunes a críticas, pelo contrário, encontram forte resistência dos teóricos substancialistas, que opõem diversas restrições às suas concepções e teses.

\subsubsection{Críticas às propostas procedimentais}

Inicialmente, é importante destacar que há dificuldade de se adotar um modelo procedimental de Constituição em países periféricos. O motivo é relativamente simples: o desenvolvimento de uma esfera pública de discussão, inclusiva e que permita a recepção de teses procedimentalistas é melhor visualizada em sociedades mais bem desenvolvidas, ou seja, em países cujas instituições e segmentos sociais tenham voz e oportunidade de dialogarem para a promoção de legislações democráticas.

Entretanto, o mesmo não se pode esperar de sociedades periféricas em que não se identificam as condições mínimas para a promoção das discussões e deliberações democráticas, em virtude de suas realidades contrastantes com países diferenciados. E essas situações fáticas não podem ser ignoradas.

A comunicação livre de restrições somente é possível quando há distribuição simétrica de oportunidades entre todos os participantes do discurso. Contudo, tais condições são utópicas, mormente nas sociedades mais desiguais, que carecem de medidas básicas de efetivação dos direitos fundamentais (CAMBI, 2016, p. 364).

Outro ponto importante diz respeito ao paradigma do Estado Democrático de Direito, que, no que toca ao constitucionalismo, adiciona um "plus” normativo ao Direito, ao que se entende por Estado Social, e dele se difere por isso. A principal diferença existente, portanto, entre o Estado Democrático e o Estado Social de Direito é a revalorização do jurídico, que caracteriza o constitucionalismo do pós-guerra, albergando mecanismos de resgate e de garantia dos direitos e valores ansiados pelas sociedades modernas. 
A legitimidade do novo paradigma está atrelada à sua tarefa transformadora do Direito, que advém da própria Constituição, e é reflexo do anterior modelo de Estado Social, no qual não se tinha plena realização de direitos fundamentais, situação, essa, agravada pelas escassas políticas públicas (STRECK, 2003, p. 266).

Dita função transformadora do Direito transfere o polo de tensão dos órgãos representativos ao Poder Judiciário ou Tribunais Constitucionais. As Constituições modernas são dotadas de um caráter dirigente, de modo que trazem em seu corpo disposições que privilegiam os direitos fundamentais, o que, de certo modo, implica reconhecer que do legislador se espera uma atuação mais acentuada e ativa, em prol desses direitos. Aliado a isso, os Tribunais naturalmente passaram a controlar as leis, não somente em seu caráter procedimental, mas materialmente, analisando a adequação de seu conteúdo à conformidade adequada em relação à Constituição.

Nesse diapasão, acerca da teoria habermasiana, Streck levanta os seguintes questionamentos:

\begin{abstract}
Daí a pergunta: como ter cidadãos plenamente autônomos, como Habermas propugna, se o problema da exclusão social não foi resolvido? Como ter cidadãos plenamente autônomos se suas relações estão colonizadas pela tradição que lhes conforma o mundo da vida? Nesse sentido, apoiado em Ackerman, pergunto: Pode uma eleição ser livre e justa, se uma grande parte do eleitorado carece de instrução necessária para compreender as principais linhas do debate político? Ou se estão passando fome ou trabalhando em condições opressivas durante a maior parte de seu tempo? "Mi respuesta es no", vai dizer Ackerman (STRECK, 2003, p. 267).
\end{abstract}

Não se pretende aqui esgotar todos esses questionamentos, tampouco formular alguma solução inequívoca a toda a problemática, contudo é indispensável ressaltar a relevância de ser considerado o contexto geral em que determinada sociedade se insere.

Na mesma medida não se pode restringir o sentido de democracia ao aspecto político e reconhecer o procedimento como única via para operá-la, principalmente, pensando-se na desigualdade que assola a sociedade.

\title{
2.2 Teoria do substancialismo
}

No campo do Estado Democrático de Direito, no que diz respeito a tomadas de decisões, por certo que pode haver erros, ou seja, podem existir falhas nos julgamentos das instituições democráticas que gerem resultados indesejáveis. Daí a necessidade de se considerar 
a importância da leitura substantiva de Constituição para correção e justiça. Tem-se, então, a defesa da teoria de que o processo democrático, se considerado apenas como procedimento, não demonstra aptidão suficiente para proteção adequada de valores substanciais.

Partindo-se dessa premissa de que nem sempre os resultados corretos são possíveis de serem garantidos, é justamente essa ausência de garantia que propicia a busca pela valoração maior de um processo justo.

Embora o processo democrático possibilite a discussão de importantes valores substantivos, ele não agasalha todos os anseios de justiça substantiva, que vão além de um processo democrático basicamente procedimental.

Nessa toada, o eixo substancialista entende que o Poder Judiciário não deve se assentar em uma postura passiva ante as realidades sociais, mas se habilitar como legítimo garantidor das promessas modernas, como reflexo do Estado Democrático de Direito.

A corrente substancial defende a existência de limites e imposições constitucionais fixados pelas Cartas Magnas, e que é dever do Estado se movimentar no sentido de positivar e implementar as ideias de justiça, estabelecendo metas a serem alcançadas com vistas ao cumprimento das finalidades constitucionais.

As atuações do Legislativo ou Executivo que contenham desvios ou compreendam omissões normativas, fazem alimentar as teorias substancialistas, pois “preconiza-se, então, um papel destacado ao Poder Judiciário na garantia e concretização dos direitos fundamentais, inclusive daqueles direitos prestacionais básicos” (ESPINOZA, 2009, p. 74).

A partir da adoção da acepção substancial da Constituição, o Poder Judiciário pode garantir a defesa dos direitos dos marginalizados politicamente, que não dispõem de meios para acessar a arena política e se constituir como parte integrante de um sistema dialogal.

Acerca do cerne das teorias substancialistas, Streck assevera que:

Em síntese, a corrente substancialista entende que, mais do que equilibrar e harmonizar os demais poderes, o judiciário deveria assumir o papel de um intérprete que põe em evidência, inclusive contra maiorias eventuais, a vontade geral implícita no direito positivo, especialmente nos textos constitucionais, e nos princípios selecionados como de valor permanente na sua cultura de origem e na do Ocidente. [...] Consequentemente, é inexorável que, com a positivação dos direitos sociais fundamentais, o poder judiciário (e, em especial, a justiça constitucional) passe a ter um papel de absoluta relevância, mormente no que pertine à jurisdição constitucional (STRECK, 2003, p. 271). 
Nota-se que esse pensamento se contrapõe à ideia de Constituição como mera folha de papel, de modo que não fica refreada às relações de poder. Na mesma linha de pensamento, não se pode admitir que a democracia seja um fim em si mesma, de modo que o bem comum não deve ser desconsiderado ou diminuído frente às vontades da maioria simplesmente (ALVES; OLIVEIRA, 2014, p. 39).

Uma das funções da Constituição é, pois, não só agasalhar direitos, não só pronunciálos, mas verdadeiramente protegê-los. Nesse sentido, considerando que há grupos sociais que não têm uma representação robusta no processo de deliberação e, portanto, seus direitos e interesses não são levados à discussão, é necessário que, de alguma forma, sejam protegidos (ALVES; OLIVEIRA, 2014, p. 39).

Na medida em que o Poder Judiciário atua de forma contramajoritária, ou não, na defesa da lei e da Constituição, a corrente substancialista defende que, ao agir desse modo, temse que se está fortalecendo a democracia e não o contrário, na medida em que se reafirma como forma de governo de todos e não somente da maioria.

\subsubsection{As Fragilidades das Teorias Substanciais}

A autocontenção judicial é o oposto do ativismo. Compreende ser a atitude pela qual o Poder Judiciário se abstém de interferir nas ações dos demais Poderes.

A partir dessa proposição, tem-se que os magistrados não aplicam a Constituição em situação de que ela não trate expressamente ou que não esteja em sua esfera de incidência; fazem uso de critérios rígidos quando da análise de eventual inconstitucionalidade de lei ou ato normativo; não tomam decisões que diretamente definem políticas públicas. A autocontenção judicial reserva às instituições e Poderes competentes a discussão sobre quais as políticas públicas devem ser privilegiadas e implementadas (BARROSO, 2012, p. 26).

Para a corrente procedimentalista, essa é a linha de atuação que o Poder Judiciário sempre deveria adotar.

Ao analisar a teoria de Habermas, Streck menciona que o autor alemão se opõe fortemente à postura substancialista ao dizer que:

Habermas faz severas críticas à leitura substancialista que Alexy faz do modelo construtivo do Direito de Dworkin e, embora a partir de outras bases, na esteira de E. 
W. Böckenfoerd, àquilo que denomina de gigantismo ou politização do judiciário, surgido no pós-guerra. A existência de tribunais constitucionais não é auto-evidente para Habermas. E, mesmo onde eles existem - e ele se restringe à Alemanha e aos Estados Unidos - há controvérsias sobre o seu lugar na estrutura de competências da ordem constitucional e sobre a legitimidade de suas decisões. Critica, assim, a idéia de concretização dos valores materiais constitucionais, aludindo que, "aos deixar-se conduzir pela idéia da realização de valores materiais, dados preliminarmente no direito constitucional, o tribunal constitucional transforma-se numa instância autoritária”. A invasão da esfera de competência dos tribunais, mediante concretizações materiais de valores, desestimula o agir orientado para fins cívicos, tornando-se o juiz e a lei as derradeiras referências de esperança para indivíduos isolados (STRECK, 2003, p. 263-264).

Embora o Poder Judiciário tenha o poder de dar a palavra última em muitas matérias, nem sempre o magistrado é o profissional mais qualificado para tanto, dando deferência para com as escolhas feitas pelo Legislativo ou para com a discricionariedade administrativa razoável do Executivo.

É preciso que se imponham limites, em nome da legitimidade democrática, em nome das capacidades institucionais do Poder Judiciário e em nome da participação no debate público. A judicialização excessiva das grandes questões políticas acaba sendo um mal porque ela afasta do debate as pessoas que não têm acesso à arena jurídica e isso não é desejado.

Embora a atuação judicial, sob o aspecto substancial, apresente uma justificativa baseada em pretensões igualitárias materialmente, pelo eixo procedimental a invasão pelo Direito na política não é desejável, tendo em vista que pode ensejar o surgimento de anomalias, ou seja, pode haver um retrocesso democrático, como a perda de liberdades, da cidadania ativa e o surgimento, como produto dessas ações, de um paternalismo estatal robusto. Em conjunto, essas circunstâncias em nada promoveriam a integração da sociedade com as questões políticas relevantes, além de gerar um grande enfraquecimento das instituições democráticas.

Uma das críticas levantadas pelos opositores do substancialismo se assenta no intervencionismo constitucional exacerbado, que altera os âmbitos de discussão da vida comunitária das deliberações políticas que, por sua vez, privilegia a cidadania ativa, para transferi-la ao paternalismo estatal (ESPINOZA, 2009, p. 74).

No ponto, ao trabalhar os termos da dicotomia entre substancialismo e procedimentalismo, Espinoza aponta mais um argumento utilizado pelos teóricos procedimentais: 
Destarte, as amplas regulações sociais empreendidas pelas Constituições contemporâneas, assim como a exigência do cumprimento dos preceitos constitucionais pela via judicial, são vistas como óbices ao exercício da democracia. E a judicialização da política representará, ao seu turno, a dissolução do espaço público democrático. Por isso, a tarefa da jurisdição constitucional não pode ir tão longe de forma a ameaçar a própria legitimidade democrática do direito, devendo seu controle estar restrito à garantia dos procedimentos democráticos e dos direitos fundamentais a eles diretamente relacionados (ESPINOZA, 2009, p. 74).

Nesse sentido, as autonomias individual e coletiva não se desenvolvem, e mesmo são suprimidas, quando deveriam constituir a base das tomadas de decisão em prol do bem estar social comum.

Como se vê, as posições extremadas, por si só, não se sustentam, seja para defender a democracia procedimental pura ou para defender o substancialismo sem respeito às instituições democráticas.

\title{
3 O PAPEL E OS LIMITES DO ATIVISMO JUDICIAL EM FACE DA CONSTITUIÇÃO
}

Segundo Fernando de Brito Alves e Guilherme Fonseca de Oliveira, o ativismo judicial "se sustenta à medida que - e somente se - o processo político falha na tutela de direitos fundamentais - notadamente no caso das minorias em razão de sua baixa participação nesse processo". Os eminentes juristas afirmam que "o ativismo não deve medir esforços na defesa de direitos de primeira dimensão” (ALVES; OLIVEIRA, 2014, p. 40).

Entretanto, alertam os autores para uma ressalva que deve ser levada em conta:

\begin{abstract}
Abordagem distinta, no entanto, merecem os direitos sociais e econômicos. A relação dialética entre mínimo existencial e reserva do possível constrói as bases da exigibilidade dos direitos de segunda dimensão. Assim, adotando a teoria das normas de Alexy, e reconhecendo a natureza principiológica dos direitos fundamentais, a ponderação no caso concreto oferece legitimidade para tutela pela via jurisdicional dos direitos fundamentais de segunda dimensão. O paradigma da igualdade fática, porém, a se reconhecer no caso concreto para esses direitos, necessariamente deve atender a critérios de racionalidade para que possa, ao fim e ao cabo, legitimar-se (ALVES; OLIVEIRA, 2014, p. 40).
\end{abstract}

Uma medida de cunho retrocessivo, além de contar com uma justificativa de porte constitucional, deve salvaguardar o núcleo essencial dos direitos sociais, notadamente naquilo em que corresponde às prestações materiais indispensáveis para uma vida com dignidade para todas as pessoas (SARLET, 2012, 464). 
Seguindo essa lógica de posicionamento, tem-se que as decisões judiciais devem ser sopesadas, com coerência, com coesão e elaboradas detidamente à luz do mínimo existencial e considerando a reserva do possível. Assim, a atuação judicial ativista, no tocante às questões mais políticas, é justificável se sua ocorrência se der de maneira restrita e responsável (ALVES; OLIVEIRA, 2014, p. 41).

Nessa toada, pode-se admitir que o ativismo judicial pode ser legitimado quando figura na defesa dos marginalizados no tocante aos processos políticos. Em contrapartida, caso se mostre de forma arbitrária e arrogante na tomada de decisões, com olhares voltados ao Poder, parece inequívoca sua rejeição.

Considerando a atual roupagem da teoria da separação de poderes, bem como a relação entre políticas públicas e atuação do Poder Judiciário, fazer a leitura de que o Poder Judiciário pode concretizar essas políticas não parece se mostrar a mais correta. Boa parte da doutrina advoga que a Constituição Federal de 1988 não dá ao Judiciário tamanho poder e liberdade, de modo que não poderia, ou ao menos não parece desejável, que o Judiciário institua ou altere eventual política pública implementada.

Entretanto, uma vez já implementada, a intervenção judicial seria legítima para evitar ou reparar violação a direito subjetivo, individual ou coletivo. Ao fazê-lo, o Poder Judiciário não implementa nada, mas somente fiscaliza tais políticas e, por consequência, dá cumprimento ao texto constitucional brasileiro. Assim, os limites constitucionais serão perfeitamente respeitados e o Judiciário estará cumprindo sua função de forma ousada e criativa, mas não se poderia falar em ativista - na acepção usurpadora de função do termo.

Neste ponto, há, então, a diferenciação entre controlar as ações políticas e ser detentor do poder de decidir politicamente. Nesse sentido,

Não há como negar que a função jurisdicional é política, em sua origem, mas isso não
lhe atribui a decisão política e sim o controle das ações políticas das demais funções,
em conformação com as normas constitucionais, as quais todos estão imbuídos de
cumprir, no estado democrático de direito. Por outro lado, também, não se está
afirmando que os juízes sejam a boca da lei; muito pelo contrário, os juízes são os que
detêm a competência para dizer se a lei está ou não de acordo com a vontade do povo,
expressa em sua lei fundamental, bem como os princípios que norteiam a sociedade
(MACHADO, 2012, p. 148).

Se de um lado se reconhece que a acepção puramente procedimental de Constituição se mostra inadequada e insuficiente frente ao Estado Democrático de Direitos, de outro também 
deve ser ressaltada a importância dos procedimentos deliberativos com a participação do cidadão para a concretude e consolidação da democracia.

Como bem argumenta Danielle Espinoza:

\begin{abstract}
Em verdade, é preciso reconhecer que tanto as teses substancialistas quanto as procedimentalistas possuem bons argumentos para a defesa do Estado Democrático de Direito. Em favor do substancialismo está a defesa peremptória dos direitos fundamentais, a ênfase na democracia social e o reforço à força normativa da Constituição através da atuação abrangente da jurisdição constitucional. Já o procedimentalismo põe em evidência a legitimação democrática das decisões públicas, a importância dos direitos à participação nos procedimentos, a ampliação da cidadania política ativa, bem como ainda alerta para os perigos dos ativismos judiciais que se assenhoram da lei e da Constituição, pondo em risco as bases da ordem democrática (ESPINOZA, 2009, p. 75).
\end{abstract}

Para que se assegure o balanceamento entre democracia e direitos fundamentais, é necessário que a realização dos valores constitucionais albergados se dê por procedimentos que também preservem um núcleo constitucional, em termos materiais.

\title{
CONSIDERAÇÕES FINAIS
}

O ativismo judicial se torna mais robusto na mesma proporção em que se nota a crise de representatividade por que passa grande parte das sociedades contemporâneas. Na medida em que a judicialização da política cresce com a esperança popular de ver realizados seus anseios e direitos imanentes do atual paradigma de Estado Democrático, o mesmo se observa com o ativismo, mas por razão diversa, agora calhado na inefetividade e omissão dos Poderes Legislativo e Executivo no trato e implemento do que Streck chama de promessas da modernidade.

A partir disso, emerge e incorpora a discussão a respeito das teorias procedimentalistas e substancialistas, de modo que é um equívoco afirmar que a adequada teoria constitucional se poria em termo com a adoção pura e simplesmente substancialista, calcada na busca pela justiça social, ou procedimentalista, dando ênfase a processos democráticos meramente formais.

Pelo contrário, essas diferentes ideologias não se excluem e, embora sejam sensíveis as relações de tensão entre ambas, parece mais acertado pensar em complemento, isso porque 
o processo democrático é sim uma forma de se buscar o justo, não se resumindo a procedimento meramente formal e abstrato, ao passo que a adoção substantiva de Constituição também pode realizar a democracia e mesmo fortalecê-la.

Teorias substancialistas extremadas são tendenciosas a realizar a democracia social sem respeitar os, não menos importantes, aspectos da democracia política, que também carecem de implemento e discussão.

De outra feita, as teorias acentuadamente procedimentalistas tendem a considerar a existência de pressupostos que muitas vezes não se fazem presentes nas realidades fática e jurídica - como uma esfera pública plenamente desenvolvida, inclusiva e autônoma -, notadamente se se ponderar sobre a real situação de sociedades periféricas.

Esses elementos dicotômicos não são estáticos, mas se aperfeiçoam e se amoldam às alterações históricas observadas na dinâmica da vida em sociedade.

Portanto, a tendência é buscar o necessário equilíbrio entre o princípio democrático e a concepção de jurisdição constitucional como apontamento da legitimidade constitucional da atuação do Poder Judiciário.

\section{REFERÊNCIAS BIBLIOGRÁFICAS}

ALVES, Fernando de Brito; OLIVEIRA, Guilherme Fonseca de. Democracia e Ativismo Judicial: atuação contramajoritária do judiciário na efetivação dos direitos fundamentais das minorias. Jacarezinho/PR: Rev. Argumenta, $n^{\circ}$ 20, p. 33-45, 2014.

BARROSO, Luís Roberto. Judicialização, Ativismo Judicial e Legitimidade Democrática. Rev. (Syn)thesis. Rio de Janeiro/RJ, v. 5, n. 1, p. 23-32. 2012. Saraiva, 2012.

O controle de constitucionalidade no direito brasileiro. 6. ed. São Paulo:

BOTELHO, Marcos César. A legitimidade da jurisdição constitucional no pensamento de Jürgen Habermas. São Paulo: Saraiva, 2010.

CARDOSO, Oscar Valente. Ativismo Judicial: Conceitos e Preconceitos. Revista Dialética de Direito Processual. São Paulo - SP, n. 129, p. 76-82, dez. 2013. ISSN 1678-3778. 
CAMBI, Eduardo. Neoconstitucionalismo e neoprocessualismo: direitos fundamentais, políticas públicas e protagonismo judiciário. São Paulo: Almedina, 2016.

DIMOULIS, Dimitri; LUNARDI, Soraya Gasparetto. Ativismo e Autocontenção Judicial no Controle de Constitucionalidade in: FELLET, André Luiz Fernandes; PAULA, Daniel Grotti de. NOVELINO, Marcelo. As Novas Faces do Ativismo Judicial. São Paulo: Jus Podvim, 2011.

ESPINOZA, Danielle Sales Echaiz. Entre Substancialismo e Procedimentalismo: elementos para uma teoria constitucional brasileira adequada. Maceió: Edufal, 2009.

MACHADO, Edinilson Donisete. Ativismo Judicial: limites institucionais democráticos e constitucionais. 1. Ed. São Paulo: Letras Jurídicas, 2012.

MELLO, Cláudio Ari. Democracia constitucional e direitos fundamentais. Porto Alegre: Livraria do Advogado, 2004.

RAMOS, Elival da Silva. Ativismo judicial: parâmetros dogmáticos. São Paulo: Saraiva, 2010.

SARLET, Ingo Wolfgang. A eficácia dos direitos fundamentais. $11^{\mathrm{a}} \mathrm{ed}$. rev. e atual. Porto Alegre: Editora do Advogado, 2012.

STRECK, Lenio Luiz. Jurisdição Constitucional e Hermenêutica: Perspectivas e Possibilidades de Concretização dos Direitos Fundamentais-Sociais no Brasil in: Novos Estudos Jurídicos. Volume 8. N 2. Porto Alegre, RS. maio/ago. 2003. p.257-301.

TEIXEIRA, Anderson Vichinkeski. Ativismo judicial: nos limites entre racionalidade jurídica e decisão política. Rev. direito GV [online]. 2012, vol.8, n.1, pp. 037-057. ISSN 1808-2432. Disponível em < http://dx.doi.org/10.1590/S1808-24322012000100002.> Acesso em 27 mar.2018. 